\title{
Рекогносцировочные работы в окрестностях грота Толеубулак B 2021 г.
}

\section{(C) 2021 г. Мамиров Т.Б., Таймагамбетов Ж.К., Куандык С.Р., Мамиров К.Б.}

Keywords: archaeology, culture, Stone Age, Paleolithic, Neolithic, Toleubulak Cave, stone tools, stone raw materials

Түйін сөздер: археология, мәдениет, тас ғасыры, палеолит, неолит, Төлеубұлақ үңгірі, тас құралдары, тас шикізат

Ключевые слова: археология, культура, каменный век, палеолит, неолит, грот Толеубулак, каменные орудия, каменное сырье

\section{Talgat Mamirov ${ }^{1}$, Zhaken Taimagambetov ${ }^{2}$, Samrat Kuandyk ${ }^{3}$, Kairat Mamirov ${ }^{4}$ \\ ${ }^{1}$ Corresponding author, Candidate of historical sciences, Deputy Director for Science, A.Kh. Margulan Archeology Institute, Almaty, Kazakhstan. E-mail: tmamirov@mail.ru ${ }^{2}$ Doctor of historical sciences, chief researcher, National Museum of the Republic of Kazakhstan, Nur-Sultan, Kazakhstan. E-mail: zhaken.taimagambetov@gmail.com \\ ${ }^{3}$ Junior researcher, A.Kh. Margulan Archeology Institute, Almaty, Kazakhstan. E-mail: s.r.kuandyk@mail.ru \\ ${ }^{4}$ Junior researcher, A.Kh. Margulan Archeology Institute, Almaty, Kazakhstan. E-mail: kairatm 1985@mail.ru}

\section{Reconnaissance works in the surroundings of Toleubulak cave in 2021}

\begin{abstract}
The article discusses the results of exploration fieldwork near the Toleubulak Cave in the Mugalzhar district of the Aktobe region in 2021. The surroundings of the Toleubulak Cave are known for archaeological sites of different times from the Paleolithic to the ethnographic time. Sites and localities with a "surface cultural horizon" represent Stone Age sites in the indicated area. The presence of a large number of springs and an abundance of stone raw materials in the area determined the tasks and methods for finding sites with preserved cultural layers. During the reconnaissance work the surroundings of the springs were examined, the pits were laid. Works of 2021 showed that the most promising are pits no. 7 and no. 8, laid near the Andakulbulak spring, with buried deposits with stone artifacts, as well as pit no. 10 northeast of the Toleubulak spring, which is the remains of a Neolithic and Eneolithic site of a mixed complex. A reconnaissance excavation was laid at the Toleubulak 3 monument opened in 2020. The excavation showed a weak concentration of artifacts over an area of 16 square meters, with thin buried sediments. The presence of stone objects in the buried layers, represented by micronucleus, chips from siliceous and jasper rocks, indicate the prospects for the discovery of Neolithic sites with a preserved cultural layer in the region under study.
\end{abstract}

Acknowledgement: The work was carried out with the financial support of the Department of Culture, Archives and Documentation of the Aktobe region.

For citation: Mamirov T., Taimagambetov Zh., Kuandyk S., Mamirov K. Reconnaissance works in the surroundings of Toleubulak cave in 2021. Kazakhstan Archeology. 2021, 4 (14), 105-120 (in Russian). DOI: 10.52967/akz2021.4.14.105.120 


\title{
Мамиров Талғат Базарбайұлы ${ }^{1}$, Таймағамбетов Жәкен Қожахметұлы², Қуандық Самрат Русланұлы ${ }^{3}$, Мамиров Қайрат Базарбайұлы ${ }^{4}$
}

1автор-корреспондент, тарих ғылымдарының кандидаты, директордың ғылым жөніндегі орынбасары, Ә.Х. Марғұлан ат. Археология институты, Алматы қ.,

Қазақстан. E-mail: tmamirov@mail.ru

2 тарих ғылымдарының докторы, бас ғылыми қызметкер, Қазақстан Республикасының Ұлттық музейі, Нұр-Сұлтан қ., Қазақстан. E-mail: zhaken.taimagambetov@gmail.com ${ }^{3}$ кіші ғылыми қызметкер, Ә.Х. Марғұлан атындағы Археология институты, Алматы, Қазақстан. E-mail: s.r.kuandyk@mail.ru

${ }^{4}$ кіші ғылыми қызметкер, Ә.Х. Марғұлан атындағы Археология институты, Алматы, Қазақстан. E-mail: kairatm_1985@mail.ru

\section{1 ж. Төлеубұлақ үңгірі маңындағы іздеу-барлау жұмыстары нәтижелері жайында}

\begin{abstract}
Аннотация. Мақалада Ақтөбе облысы Мұғалжар ауданындағы Төлеубұлақ үңгірі маңындағы 2021 ж. далалық жұмыстардың барлау нәтижелері қарастырылған. Төлеубұлақ үңгірі маңы палеолиттен этнографиялық уақытқа дейінгі әр түрлі кезеңдік археологиялық ескерткіштермен танымал. Осы аудандағы тас ғасыры ескерткіштері «беткі мәдени қабаты» бар тұрақтар және табылу орындарымен көрсетілген. Бұлақтардың көп болуы және жердегі тас шикізатының көптігі сақталған мәдени қабаттары бар ескерткіштерді іздеудің міндеттері мен әдістерін анықтады. Рекогносцивті жұмыстар барысында бұлақтар маңы қаралып, шурфтар қазылды. 2021 ж. жұмыстар тас жәдігерлері бар жерлеу шөгінділерімен бірге Андакүлбұлақ бұлағы жанында қазылған № 7 және № 8 шурфтар және де неолиттік-энеолиттік кезеңге, аралас кешенге жататын табылу орны қалдықтары болып табылатын Төлеубұлақ бұлағының солтүстік-шығысындағы № 10 шурфтың келешегінен үміт бар. 2020 ж.

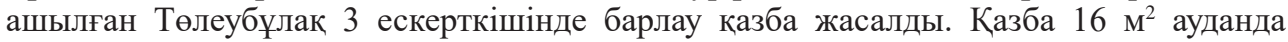
аз қабатты жерлеу шөгінділері бар жәдігерлердің әлсіз концентрациясын көрсетті. Жерлеу қабаттарында микронуклеустармен, кремний және яшма тәрізді жыныстардан өңделген сынықтармен көрсетілген тас бұйымдар зерттеліп отырған аймақта мәдени қабаттары бар неолиттік ескерткіштердің ашылуының келешегін дәлелдейді.
\end{abstract}

Алғыс: Жұмыс Ақтөбе облысының мәдениет, архивтер және құжаттама басқармасының қаржылық қолдауы бойынша жасалды.

Сілтеме жасау үшін: Мамиров Т.Б., Таймағамбетов Ж.Қ., Қуандық С.Р., Мамиров Қ.Б. 2021 ж. Төлеубұлақ үңгірі маңындағы іздеу-барлау жұмыстары нәтижелері жайында. Қазақстан археологиясы. 2021. № 4 (14). 105-120-бб. (Орысша). DOI: 10.52967/akz2021.4.14.105.120

\section{Мамиров Талгат Базарбаевич ${ }^{1}$, Таймагамбетов Жакен Кожахметович르, Куандык Самрат Русланулы ${ }^{3}$, Мамиров Кайрат Базарбаевич ${ }^{4}$}

${ }^{1}$ автор-корреспондент, кандидат исторических наук, заместитель директора по науке, Институт археологии им. А.Х. Маргулана, г. Алматы, Казахстан.

E-mail: tmamirov@mail.ru

${ }^{2}$ доктор исторических наук, главный научный сотрудник, Национальный музей Республики Казахстан, г. Нур-Султан, Казахстан.

E-mail: zhaken.taimagambetov@gmail.com

${ }^{3}$ младший научный сотрудник, Институт археологии им. А.Х. Маргулана,

г. Алматы, Казахстан. E-mail: s.r.kuandyk@mail.ru

${ }^{4}$ младший научный сотрудник, Институт археологии им. А.Х. Маргулана, г. Алматы, Казахстан. E-mail: kairatm_1985@mail.ru 
Аннотация. В статье рассматриваются результаты разведочных полевых работ, проводившихся в окрестностях грота Толеубулак (Мугалжарский р-н, Актюбинская обл.) в 2021 г. Окрестности грота Толеубулак известны разновременными археологическими памятниками от эпохи палеолита до этнографического времени. Памятники каменного века в указанном районе представлены стоянками и местонахождениями с «поверхностным культурным горизонтом». Наличие большого количества родников и обилие каменного сырья на местности определили задачи и методы по поиску памятников с сохранившимися культурными слоями. В ходе рекогносцировочных работ были осмотрены окрестности родников, заложены шурфы. Работы 2021 г. показали, что наиболее перспективными являются шурфы № 7 и 8, заложенные возле родника Андакулбулак, с погребенными культурными отложениями, содержащими каменные артефакы, а также шурф № 10 северо-восточнее родника Толеубулак, представляющий собой остатки местонахождения неолит-энеолитического времени, смешанного комплекса. Был заложен рекогносцировочный раскоп на памятнике Толеубулак 3, открытом в 2020 г. Раскоп показал слабую концентрацию артефактов на площади 16 кв. м. с маломощными погребенными отложениями. Наличие в погребенных слоях каменных изделий, представленных микронуклеусом, сколами из кремнистой и яшмовидной породы, свидетельствует о перспективности открытия неолитических стоянок с сохранившимся культурным слоем в исследуемом регионе.

Благодарности: Работа выполнена при финансовой поддержке управления культуры, архивов и документации Актюбинской области.

Для цитирования: Мамиров Т.Б., Таймагамбетов Ж.К., Куандык С.Р., Мамиров К.Б. Рекогносцировочные работы в окрестностях грота Толеубулак в 2021 г. Археология Казахстана. 2021. № 4 (14). C. 105-120. DOI: 10.52967/akz2021.4.14.105.120

\section{Введение}

В 2021 г. одним из направлений работ археологического отряда Института археологии им. А.Х. Маргулана стала закладка рекогносцировочных шурфов возле родников, встречающихся в большом количестве в окрестностях грота Толеубулак. В физико-географическом отношении данный регион интересен тем, что здесь, в месте слияния многочисленных родников с предгорий Мугалжарских гор, берет начало р. Жем. Местность Толеубулак известна как большой археологический комплекс, функционирововший с палеолита по этнографическое время [Деревянко и др. 1999; Деревянко и др. 2001 ; Деревянко и др. 2001б; Деревянко и др. 2003; Таймагамбетов и др. 2010]. Здесь же располагается уникальный памятник наскального искусства грот Толеубулак, объект поклонения с неолитического времени [Самашев 2006; Сойкина 2009; Таймагамбетов и др. 2016; Таймагамбетов 2020]. В ходе археологических обследований были зафиксированы могильник эпохи бронзы, курганы эпохи раннего железного века, казахские кладбища, стоянки, петроглифы, а на могильнике эпохи бронзы был раскопан каменный ящик, отнесенный к алакульской культурной группе [Онгар и др. 2006]. Однако, свидетельств наличия памятников неолита-энеолита, которыми датируются самые ранние композиции Большого грота Толеубулак, не было отмечено до 2020 г. Предварительные работы в 2020 г. показали перспективность обнаружения погре- 
бенных культурных слоев, когда возле родников Толеубулак и Андакулбулак было обнаружено несколько каменных орудий неолитического облика из яшмовидного и кремнистого сырья [Мамиров и др. 2020]. Поэтому в 2021 г. одним из направлений работ стало исследование шурфами окрестностей родников возле грота Толеубулак для обнаружения погребенных культурных горизонтов с остатками жизнедеятельности древних насельников региона.

Методика исследований и описание материала

В 2021 г. был проведен подробный осмотр окрестностей грота Толеубулак с фиксацией постоянно и временно действующих родников. Родники сосредоточены преимущественно на склоновых и пойменных участках правого берега долины р. Жем (рис. 1).
Первый пункт обследования расположен в 1,5 км к югу от озера Туздыколь (ныне солончак), в 2,3 км к северо-западу от грота Толеубулак. Местность представляет собой песчаный массив, вытянутый по направлению северо-запад-юго-восток, протяженностью 1 км, в 80-100 м к востоку от родника Шибулак, окруженного небольшим лесным массивом. На дневной поверхности прослеживались выходы кварцитовидного песчаника светло-серых оттенков с единичным артефактом - отщепом с нерегулярной ретушью размерами $104 \times 97 \times 32$ мм (провертка?) (рис. 2, 1). Шурф № 1, заложенный в песчаном массиве, не показал наличия погребенных слоев.

В 1,5 км к юго-востоку от грота Толеубулак и в 170 м к востоку от одноименного родника был обследован делювиальный склон с выходами обломков кварцитовидного песчаника. В месте их наибольшего скопления был

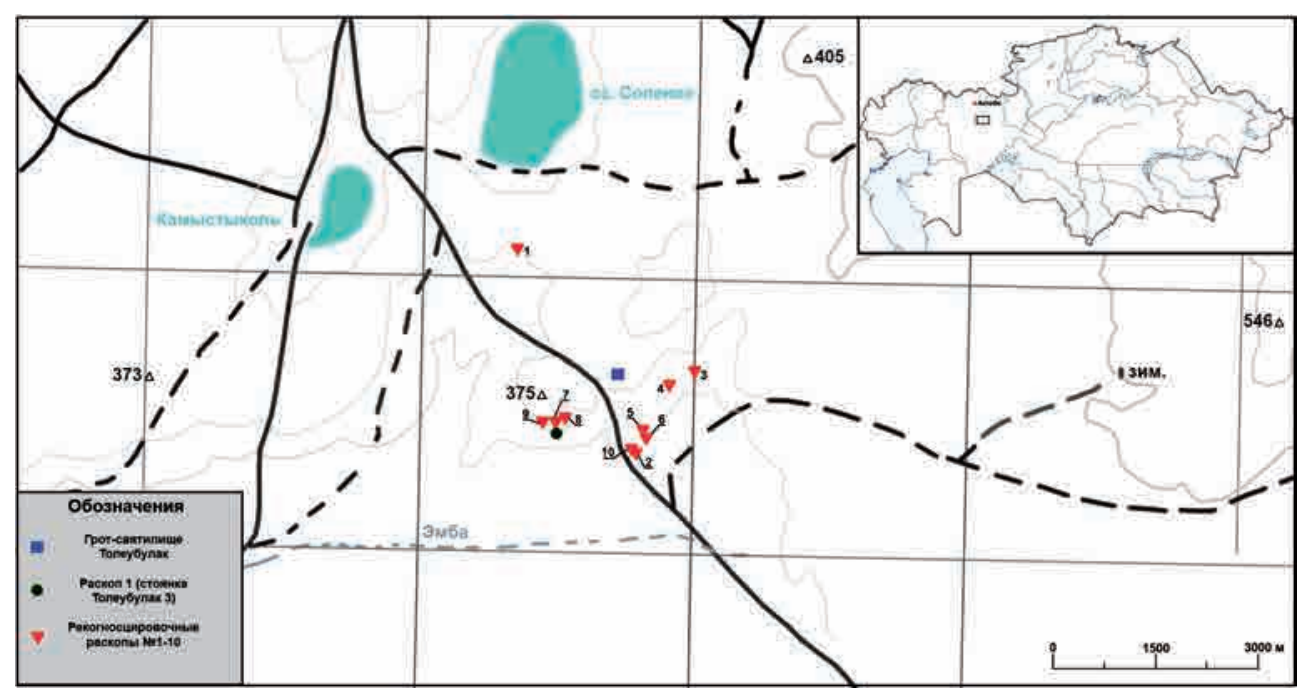

Рис. 1. Карта-схема расположения шурфов 2021 г. в окрестности грота Толеубулак 1-сур. Төлеубұлақ үңгірі маңындағы 2021 ж. жасалған шурфтардың орналасу карта-схемасы

Fig. 1. Schematic map of the pits excavated in 2021 in the surroundings of Toleubulak cave 


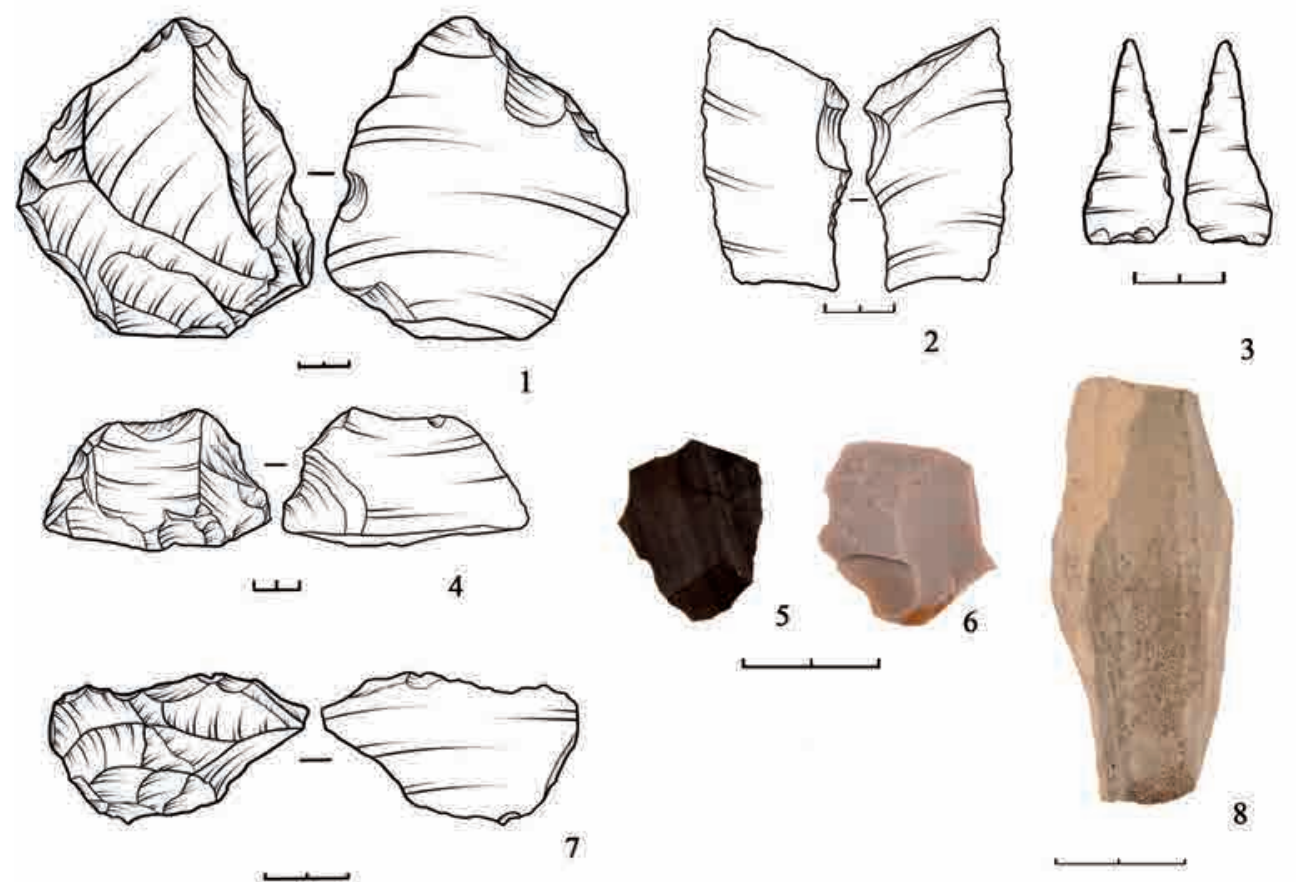

Рис. 2. Толеубулак. Каменные артефакты, 2021 г.: 1 - каменное орудие с поверхности шурфа № 1; 2 - зубчатое орудие. Шурф № 2, гл. 30-40 см; 3 - острие. Шурф № 3, гл. 20-30 см; 4 - отщеп с ретушью. Шурф № 10, гл. 40-60 см; 5-6 - отщепы с ретушью. Шурф № 10, гл. 0-20 см; 7 - скребло. Шурф № 10, гл. 40-60 см;

8 - призматический нуклеус возле шурфа № 10, подъемные сборы

2-сур. Төлеубұлақ. Тас жәдігерлер, 2021 ж.: 1 - № 1 шурф бетіндегі тас құрал; 2 - тісті құрал. № 2 шурф, тер. 30-40 см; 3 - үшкір. № 3 шурф, тер. 20-30 см; 4 - өңделген отщеп. № 10 шурф, тер. 40-60 см; 5-6 - өңделген отщеп. № 10 шурф, тер. 0-20 см;

7 - қырғыш. № 10 шурф, тер. 40-60 см; 8 - № 10 шурф маңындағы призмалық нуклеус, беткі жиындар

Fig. 2. Toleubulak. Stone artifacts, 2021: 1 - stone tool from the surface of pits no. 1; 2 - serrated tool.

Pit no. 2, depth 30-40 cm; 3 - spearhead. Pit no. 3, depth $20-30 \mathrm{~cm} ; 4$ - flake with retouching.

Pit no. 10, depth 40-60 cm; 5-6 - flakes with retouching. Pit no. 10, depth 0-20 cm; 7 - scraper.

Pit no. 10 , depth $40-60 \mathrm{~cm} ; 8-$ prismatic core near pit no. 10 , lifting assemblages

заложен шурф № 2 размерами $2 \times 1$ м, глубиной до 0,6 м (до материкового суглинка светло-коричневого цвета).

При послойном (10 см) снятии грунта были обнаружены 16 артефактов из кварцитовидного песчаника.

С глубины 0-10 см происходят три скола без вторичной обработки.

В следующем слое на глубине 10-20 см был зафиксирован массивный отбойник размерами $133 \times 62 \times 46$ мм. Обушковая сторона подработана сколами для аккомодации. На рабочем конце изделия прослеживается сильная забитость от утилизации.

На глубине 20-30 см было найдено пять артефактов. Среди них выделяется единственное орудие - острие из подтреугольного скола из кварцитовидного песчаника светло-серого 
цвета размерами $45 \times 19 \times 5$ мм. Дистальная часть изделия заострена, края подправлены ретушью (рис. 2, 3).

На глубине 30-40 см было раскопано три артефакта - маловыразительные фрагменты вторичных сколов.

С глубины 40-50 см извлечены два артефакта: нуклевидный обломок и отщеп с ретушью размерами $72 \times 44 \times 10$ мм. Правый край изделия подправлен обратной зубчатой ретушью (рис. 2, 2).

На глубине 50-60 см обнаружено два артефакта: скол с обушком и концевой скребок на отщепе.

В 1,2 км к востоку от грота Толеубулак была обследована территория возле родника Акбулак (рис. 3). Шурф № 3 был заложен на пойменной части древнего русла, где функционирует родник Акбулак. Размеры шурфа $2 \times 1$ м, глубина до 0,6 м. В шурфе артефакты не были обнаружены.

Стратиграфия шурфа представлена следующим образом:

0-5 см - дерновый слой;

5-13 см - супесь светло-серого цвета;
13-20 см - комковатая супесь серого цвета;

20-37 см - супесь серого цвета с примесью карбонатов;

37-55 см - суглинок желтоватосерого цвета с примесью карбонатов;

55-60 см - суглинок светлокоричневого цвета.

В 0,8 км к востоку-юго-востоку от грота Толеубулак, была обследована территория возле родника Мибулак (рис. 3). На первой надпойменной террасе был заложен рекогносцировочный шурф № 4 размерами $2 \times 1$ м, глубиной до 1,1 м.

Раскоп производился послойно по 20 см. На глубине 60-80 см были обнаружены два неопределимых фрагмента костей, а также один нуклевидный обломок из кварцитовидного песчаника размерами $38 \times 31 \times 17$ мм.

Шурфом вскрыты следующие отложения:

0-12 см - дерновый слой;

12-55 см - супесь темно-серого цвета;

55-96 см - суглинок светлосерого цвета;

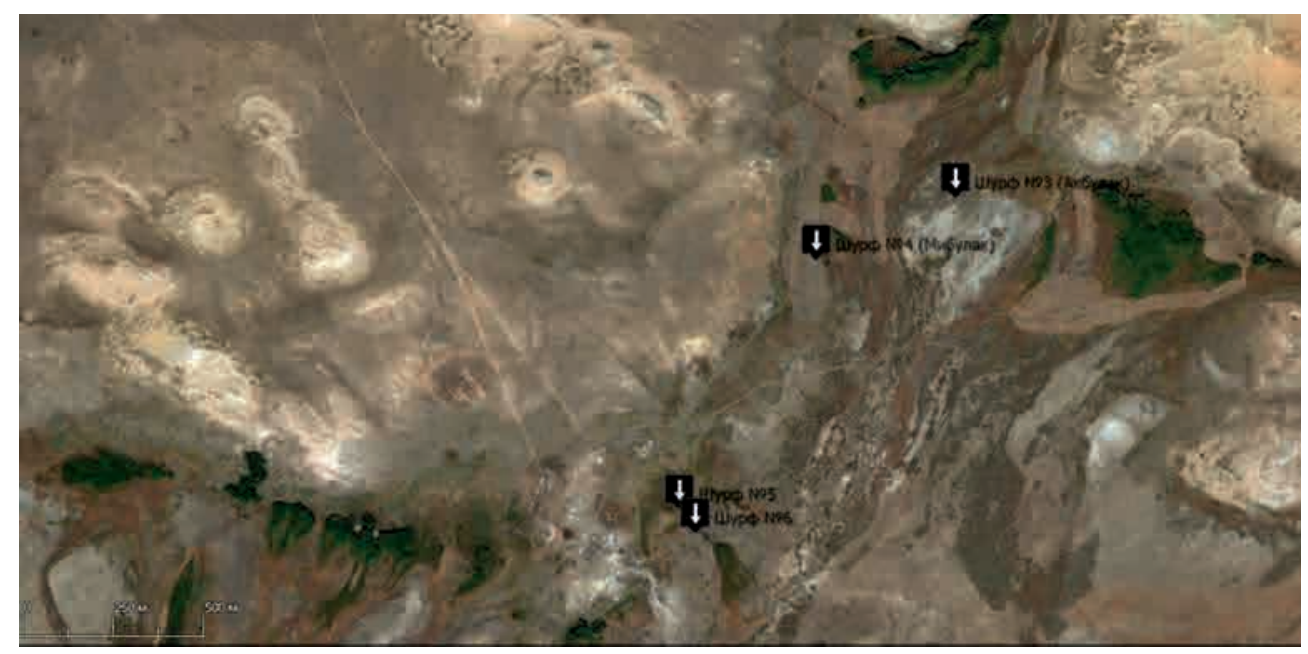

Рис. 3. Схема расположения шурфов № 3-6 в окрестности грота Толеубулак 3-сур. Төлеубұлақ үңгірі маңындағы № 3-6 шурфтарының орналасу схемасы Fig. 3. Scheme of the location of pits no. 3-6 in the surroundings of Toleubulak cave 
96-110 см - суглинок коричневого цвета.

В 1 км к юго-востоку от грота Толеубулак была обследована терраса возле небольшого родника Имашбулак. В настоящее время у родника сооружена земляная дамба (рис. 3). По правому борту родника на террасе и склоне были пройдены шурфы № 5 и 6 размерами $2 \times 1$ и $1 \times 1$ м соответственно, глубиной до $40 \mathrm{~cm}$ (до подстилающего суглинка светлокоричневого цвета).

При прохождении шурфов артефакты не были обнаружены, сами рыхлые отложения маломощные, чуть более 20 см, подстилаются материковыми слоями суглинка.

В 1,2 км к юго-западу от грота Толеубулак и в 25 м к северу от памятника Толеубулак 3, обнаруженного в 2020 г., были осмотрены участки террасы, возвышающейся над родником Андакулбулак возле развалин Кызай (рис. 4, 1). Шурф № 7 размерами $1 \times 1$ м был заложен на западной окраине урочища.

Стратиграфия шурфа выглядит следующим образом:

5-13 - дерновый слой;

13-23 - супесь темно-серого цвета;

23-37 - супесь светло-серого цвета;

37-58 - ожелезненный суглинок рыжеватого цвета;

57-70 - суглинок желтоватосерого цвета.

В ходе работ на разных глубинах были получены следующие артефакты.

На глубине 0-20 см был обнаружен неопределимый фрагмент кости, а также два плохо сохранившихся фрагмента керамики размерами $2 \times 2 \mathrm{~cm}$.
На глубине 20-40 см зафиксированы артефакты:

- боковой скребок на отщепе размерами $63 \times 71 \times 16$ мм. Рабочая часть расположена на левом выпуклом крае, обработана субпараллельной глубокой ретушью (рис. 4, 2);

- дистальный фрагмент пластинчатого отщепа размерами $26 \times 16 \times 8$ мм без следов вторичной обработки;

- два массивных обломка вторичных отщепов без вторичной обработки размерами $45 \times 63 \times 20$ мм и $33 \times 55 \times 17$ мм;

- два мелких фрагмента костей, предположительно МРС;

- два фрагмента лепного сосуда.

На глубине 40-60 см был обнаружен один массивный нуклевидный обломок вытянутой формы размерами $213 \times 79 \times 60$ мм со следами сколов опробования.

В 30 м к северо-востоку от шурфа № 7, на участке гипсометрически выше него был заложен шурф № 8 размерами $1 \times 1$ м, глубиной $1 \mathrm{M}$ (рис. 4, 3).

Шурфом вскрыты отложения:

0-15 см - дерновый слой;

15-33 см - супесь светло-серого цвета;

33-60 см - комковатая супесь серого цвета;

60-88 см - супесь серого цвета; 88-100 - суглинок желтоватосерого цвета.

На глубине 0-20 см было обнаружено два неопределимых фрагмента костей и три фрагмента керамики размерами $1,5 \times 2$ см. Также в этом слое был обнаружен целый вторичный отщеп без обработки размерами $62 \times 65 \times 16$ мм.

На глубине 20-40 см были обнаружены три неопределимых фрагмента костей и три фрагмента керамики. 

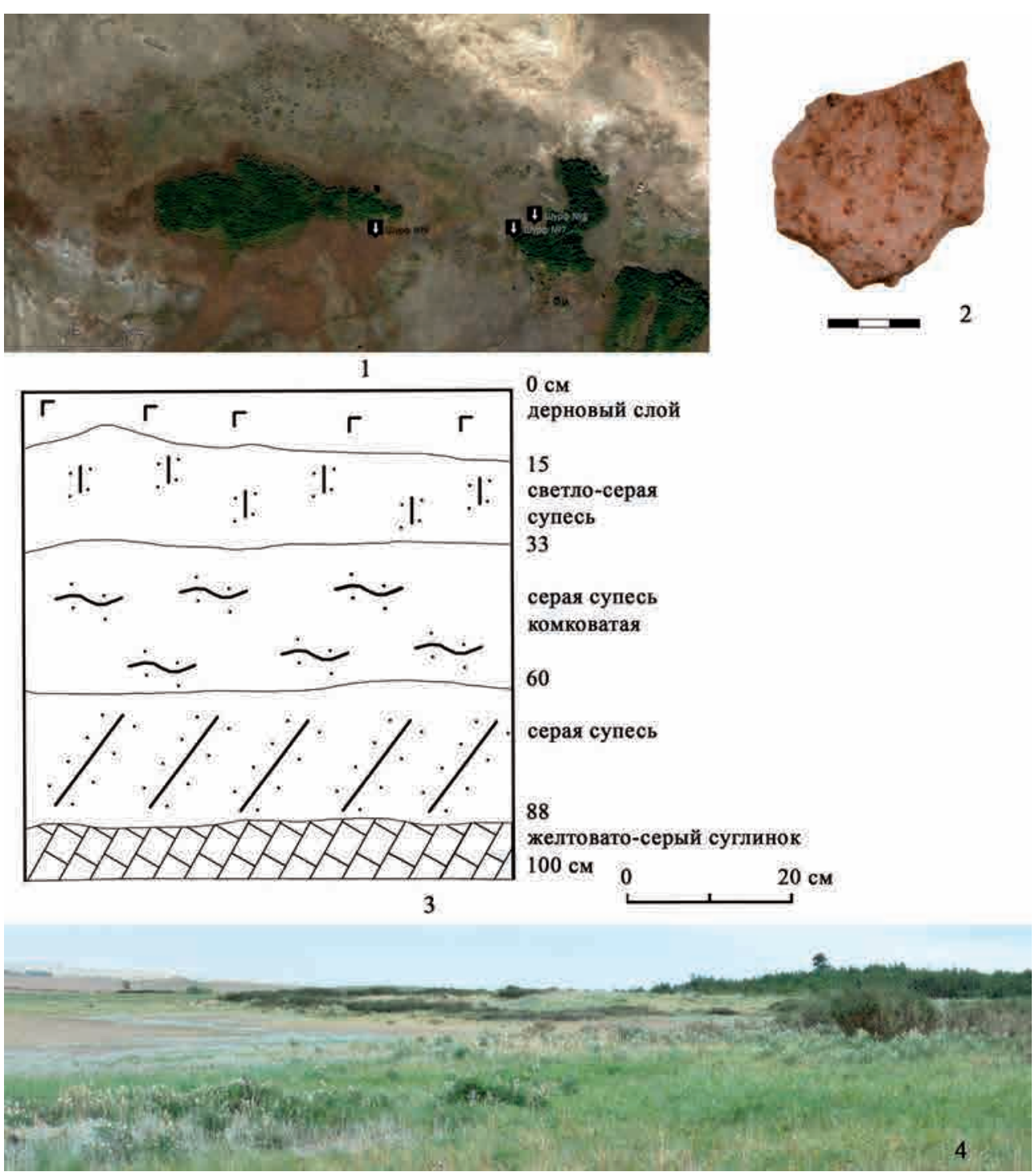

Рис. 4. Окрестности грота Толеубулак, 2021 г.: 1 - схема расположения шурфов № 7-9; 2 - боковой скребок. Шурф № 7, гл. 20-40 см;

3 - стратиграфический разрез северной стенки шурфа № 8; 4 - место расположения шурфа № 9

4-сур. Төлеубұлақ үңгірі маңы, 2021 ж.: 1 -№ 7-9 шурфтарының орналасу схемасы; 2 - жанындағы қырғыш. № 7 шурф, тер. 20-40 см; 3 - № 8 шурфтың солтүстік қабырғасының стратиграфиялық қимасы; 4 - № 9 шурфтың орналасу орны

Fig. 4. Surroundings of Toleubulak cave, 2021: 1 - scheme of location of pits no. 7-9; 2 - scraper. Pit no. 7, depth $20-40 \mathrm{~cm} ; 3-$ stratigraphic section of the northern wall of pits no. $8 ; 4$ - location of pits no. 9

На глубине 40-60 см было обнаружено шесть фрагментов костей (два астрагала мелкого рогатого скота), один фрагмент керамики размерами $45 \times 31 \times 8$ мм и два каменных обломка размерами $28 \times 14 \times 9$ мм и $22 \times 19 \times 10 \mathrm{Mm}$.

На глубине 60-80 см было зафиксировано 10 фрагментов костей, семь фрагментов керамики и два вто- 
ричных отщепа без обработки размерами $48 \times 29 \times 14$ мм и $44 \times 22 \times 8$ мм.

С глубины 80-100 см происходят: фрагмент керамики размерами $23 \times 39 \times 8$ мм, вторичный отщеп без обработки размерами $33 \times 34 \times 5$ мм и три обломка размерами 2,5-6 см.

Отложения в шурфе, особенно в верхних слоях, сильно перемешаны в результате антропогенного воздействия в этнографическое и современное время.

В 1,3 км к юго-западу от грота Толеубулак и в 173 м к западу от стоянки Толеубулак 3 была обследована первая надпойменная терраса (рис. 4, 4). На дневной поверхности прослеживались выходы кварцитовидных песчаников красноватого и серого цветов. На террасе был заложен шурф № 9 размерами $1 \times 1$ м, глубиной $1,1 \mathrm{~m}$.

Стратиграфия шурфа:

0-10 см - дерновый слой;

10-28 см - супесь серого цвета;

28-50 см - супесь темно-серого цвета;

50-90 см - песок бежевого цвета;

90-110 см - суглинок желтоватосерого цвета, ожелезненный.

В северной и восточной стенках прослеживается линза илистых образований черного цвета с примесью кварцитовидного песчаника, мощностью от 5 до 20 см с уклоном к северовостоку.

На глубине 0-20 см был обнаружен фрагмент керамики размерами $22 \times 11 \times 7$ мм, а также нуклевидный обломок размерами 49×25×15 мм. Обломок имеет негативы трех сколов опробования шириной от 7 до 16 мм.

На глубине 20-40 см были встречены: дистальный фрагмент пластины размерами $31 \times 34 \times 15$ мм; вторичный отщеп размерами $52 \times 48 \times 13$ мм.
Шурф № 10 был заложен в 1,1 км к юго-востоку от грота Толеубулак, в непосредственной близости от полевого стана на первой надпойменной террасе. Размеры шурфа $1 \times 1$ м, глубина до 0,65 м.

Стратиграфия шурфа представлена следующими отложениями:

0-10 см - дерновый слой;

10-13 см - супесь светлокаштанового цвета;

13-15 см - супесь гумусированная темно-коричневого цвета;

15-25 см - супесь темно-серого цвета;

25-35 см - супесь светло-серого цвета;

35-60 см - суглинок ожелезненный рыжеватого цвета;

60-65 см - суглинок желтоватосерого цвета.

На глубине 0-20 см были обнаружены:

- заготовка бифасиального орудия на массивном сколе размерами $102 \times 82 \times 40$ мм. Изделие в сечении линзовидной формы, равномерно выпуклое, поверхности подготовлены конвергентными сколами. Ударная площадка скола прямая, гладкая, образована одним снятием. Дистальная часть уплощена тремя сколами. Края прямые крутые, со следами забитости;

- зубчатое орудие на полукраевом отщепе размерами $86 \times 104 \times 22$ мм. Ударная площадка отщепа двугранная асимметричная. Дистал скошен к правому краю, обработан зубчатой ретушью. Левый край прямой, острый. Правый - прямой острый, обработан зубчатой ретушью (правый край и дистальный образуют сплошное лезвие); 
- пластина с ретушью представляет собой дистальный фрагмент размерами $33 \times 40 \times 14$ мм. Левый край прямой острый подправлен обратной субпараллельной ретушью, правый край - прямой, крутой, обработан лицевой субпараллельной ретушью;

- вторичный отщеп из кремня бежевого цвета размерами $26 \times 26 \times 6,5 \mathrm{Mм}$ (рис. 2, 6);

- отщеп с ретушью утилизации из кремня темно-серого цвета размерами $26 \times 21,5 \times 3,5$ мм. Спинка уплощенная с негативами бессистемных снятий. Левый край выпуклый, острый с повреждениями. Правый край прямой острый, несет лицевую мелкую ретушь утилизации (рис. 2, 5);

- обломок орудия из кремня черного цвета размерами $16 \times 38 \times 13$ мм. Спинка выпуклая с негативами пяти конвергентных сколов, одна из граней обработана субпараллельной ретушью;

- осколок кремня серого цвета с коричневым оттенком размерами $22 \times 25 \times 5$ мм;

- отбойник

размерами

$67 \times 54 \times 39$ мм.

На глубине 20-40 см выявлены:

- нуклеус из отщепа округлой формы размерами $88 \times 78 \times 36$ мм. Фронт выпуклый с негативами снятия укороченных сколов, контрфронт - поперечное ребро, скошенное к дисталу. Дистал выпуклый местами корочный. Ударная площадка выпуклая подготовлена одним снятием. Площадь скалывания занимает более 50\% периметра изделия;

- отщеп с ретушью ромбовидной формы размерами $53 \times 39 \times 15$ мм. Левый край изделия выпуклый, крутой, вместе с дистальной частью образует рабочий край, оформленный чередующейся ретушью. Правый край - обушок;

- отщеп с ретушью утилизации размерами $56 \times 52 \times 10$ мм. Левый край стрельчатый острый с обломами, правый - выпуклый острый, имеет ретушь утилизации;

- пластина без вторичной обработки размерами $36 \times 14 \times 7$ мм, с трехгранной асимметричной спинкой. Ударная площадка образована одним снятием. Левый край выпуклый, крутой, правый - прямой крутой;

- медиальный фрагмент пластины без вторичной обработки размерами $16 \times 17 \times 4$ мм с двугранной асимметричной спинкой;

- краевой отщеп из кремнистой породы размерами $25 \times 32 \times 4$ мм;

- два осколка размерами 1,23,5 см без вторичной обработки.

На глубине 40-60 см обнаружены:

- технический скол размерами $37 \times 63 \times 29$ мм - скол оживления ударной площадки нуклеуса («таблетка»). Ударная площадка нуклеуса гладкая, образована одним снятием. Фронт скалывания занимает $3 / 4$ периметра изделия, сохранились негативы снятия пластинчатых отщепов шириной от 17 до 40 мм;

- отщеп с ретушью утилизации полукраевой трапециевидной формы размерами $59 \times 97 \times 27$ мм. Проксимальная часть обломана, вогнутая. Левый край выпуклый крутой, притуплен ретушью утилизации, правый - угловатый с обломами (рис. 2, 4);

- скребло поперечное вогнутое на отщепе сердцевидной формы размерами $36 \times 61 \times 14$ мм. На дистальном конце вогнутое лезвие отделано глубокой субпараллельной ретушью. Левый край - прямой отвесный, правый - вогнутый острый (рис. 2, 7); 
- ножи с обушками (3 экз.) размерами: $127 \times 47 \times 30,112 \times 60 \times 32$, $90 \times 31 \times 18$ мм. У первого спинка двугранная асимметричная выпуклая. Ударная площадка скошена. Левый край - обушок, правый край прямой, имеет чередующуюся ретушь; у второго - спинка уплощенная. Ударная площадка прямая, гладкая, образована одним снятием. Правый край - обушок. Левый - прямой острый, с чередующейся ретушью; у третьего ножа спинка двугранная асимметричная, выпуклая. Ударная площадка прямая, гладкая, образована одним снятием. Левый край - выпуклый обушок, правый край вогнутый, подправлен субпараллельной ретушью;

- два вторичных отщепа без подправки размерами $33 \times 50 \times 20$ мм и $42 \times 47 \times 8$ мм;

- обломок орудия размерами $48 \times 47 \times 23$ мм, один край обработан глубокой субпараллельной ретушью.

В 2021 г., на правом берегу родника Андакулбулак, в месте, где был пройден шурф 2020 г. (Толеубулак 3), был заложен рекогносцировочный раскоп площадью 16 кв. м (рис. 5, 1). В 2020 г. на глубине около 20 см выявлено три артефакта из кремнистых пород: медиальный фрагмент пластины, полукраевой скол с микроретушью и технический скол с площадки призматического нуклеуса для снятия пластин из кремня черного цвета (рис. 5, 6-8).

В раскопе 2021 г. вскрытие рыхлых отложений производилось с просеиванием грунта. Глубина раскопа составила 40 см, до материковых отложений, представленных светлосерыми суглинками.

На глубине 0-20 см было обнаружено 20 каменных артефактов и два фрагмента керамики.
Орудийный набор представлен следующими типами:

- топор треугольной формы размерами $43 \times 81 \times 34$ мм. Поверхности уплощенные, с несколькими сколами подправки. Края слабо выпуклые отвесные, скошенные к основанию. Лезвие широкое, обработано глубокой бифасиальной ретушью, с забитостями (рис. 5, 2);

- массивный отбойник округлой формы размерами $136 \times 125 \times 54$ мм со следами утилизации;

- отщеп с ретушью размерами $53 \times 32 \times 14$ мм. Края отщепа прямые крутые, правый с ретушью утилизации. Дистальная часть выпуклая острая с лицевой зубчатой ретушью;

- отщеп с ретушью утилизации полукраевой, из кремня бежевого цвета размерами $21 \times 34 \times 7$ мм. Дистальная часть отщепа - лезвие выпуклое острое, с ретушью утилизации;

- отщеп с ретушью - дистальный фрагмент размерами $28 \times 28 \times 12$ мм. Края отщепа выпуклые, левый крутой, правый - острый, с обратной зубчатой ретушью;

- сколы без вторичной обработки: медиальный фрагмент пластины, три вторичных отщепа, один полукраевой отщеп, восемь фрагментов сколов и два нуклевидных обломка, на одном имеются следы снятия сколов опробования;

- два фрагмента керамики размерами $32 \times 30 \times 8$ мм и $23 \times 14 \times 8$ мм.

На глубине 20-40 см было зафиксировано 12 каменных артефактов и восемь фрагментов керамики.

К орудиям можно отнести следующие артефакты:

- отщеп с ретушью овальной формы размерами $98 \times 116 \times 40$ мм. Лезвие на левом краю подправлено 

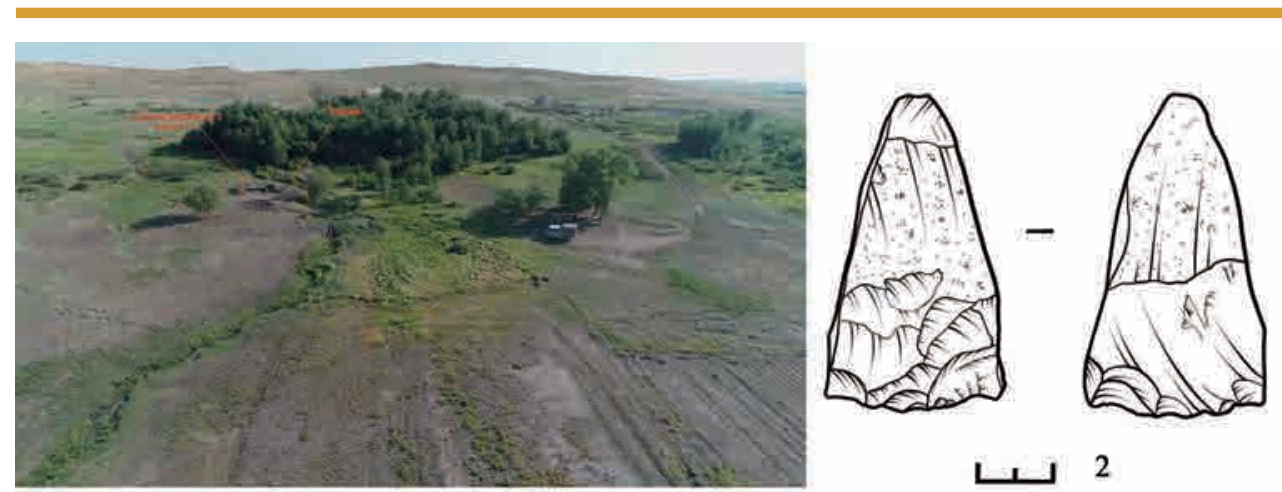

1
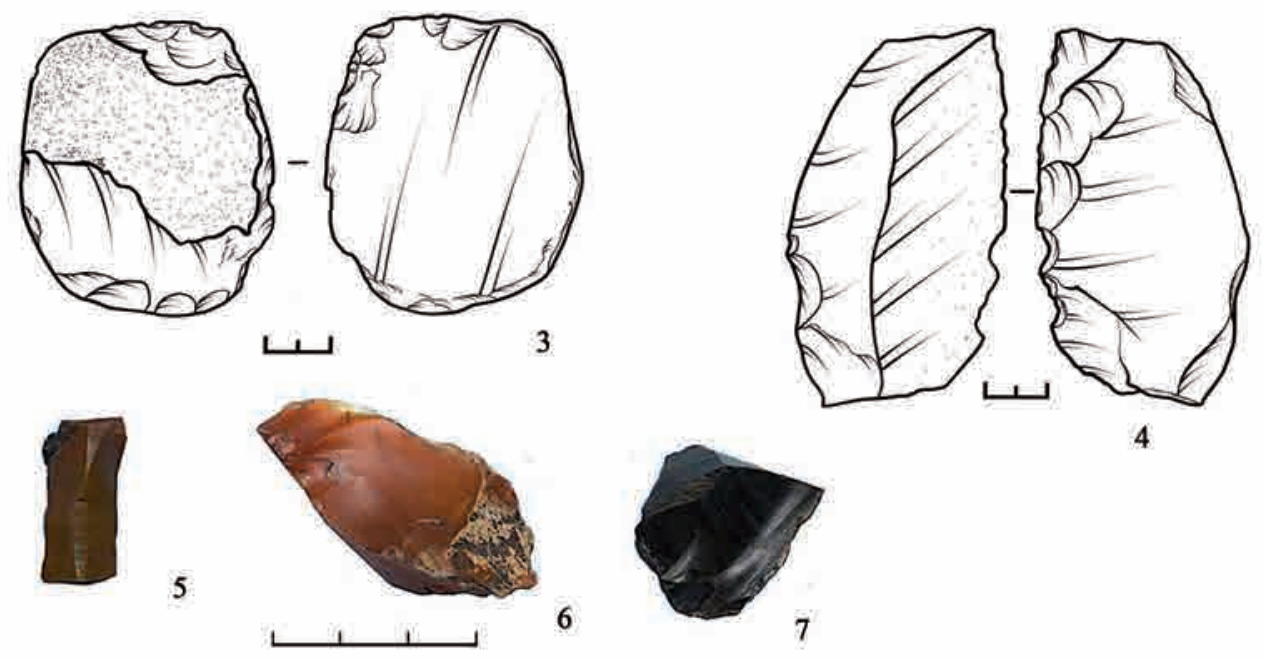

Рис. 5. Стоянка Толеубулак 3, 2021 г.: 1 - вид на стоянку Толеубулак 3; 2 - топор, гл. 0-20 см; 3-4 - каменные орудия, гл. 20-40 см; 5-7 - орудия и технический скол, материал 2020 г.

5-сур. Төлеубұлақ 3 тұрағы, 2021 ж.: 1 - Төлеубұлақ 3 тұрағына қараған көрініс; 2 - балта, тер. 0-20 см; 3-4 - тас құралдар, тер. 20-40 см; 5-7 - құрал және техникалық сынық, 2020 ж. материалы

Fig. 5. Site Toleubulak 3, 2021: 1 - view of the site Toleubulak 3; 2 - axe, dept 0-20 cm; 3-4 - stone tools, ch. $20-40 \mathrm{~cm} ; 5-7$ - tools and technical scrap, material 2020

бифасиальной ретушью. Правый и дистальный края изделия обработаны субпараллельной ретушью;

- скребло боковое на отщепе овальной формы размерами $64 \times 60 \times 17$ мм. Правый край отщепа выпуклый крутой, подработан глубокой субпараллельной ретушью;

- отщеп с бифасиальной ретушью (чоппинговидное орудие) оваль- ной формы размерами $86 \times 72 \times 20$ мм. Одна поверхность уплощенная, наполовину покрыта коркой, другая - слабовыпуклая. Левый край прямой, обушок. Правый край выпуклый крутой, вместе с дистальной частью изделия образуют лезвие, оформленное бифасиальной ретушью (рис. 5, 3);

- отщеп с ретушью, пластинчатый, листовидной формы размерами 
$114 \times 47 \times 25$ мм. Спинка двугранная асимметричная, выпуклая. Левый край вогнутый, крутой, обработан лицевой зубчатой ретушью, правый выпуклый, массивный;

- концевой скребок на полукраевом отщепе из полупрозрачного кремня темно-серого цвета размерами $20 \times 24 \times 5$ мм. Левый край отщепа выпуклый крутой, правый - обломан, вогнутый. Дистальная часть - выпуклое лезвие, с мелкой глубокой субпараллельной ретушью;

- нож с обушком из пластинчатого отщепа листовидной формы из кварцитовидного песчаника красноватого цвета размерами $114 \times 67 \times 38$ мм. Спинка двугранная асимметричная. Левый край выпуклый крутой, правый - выпуклый острый, подправлен обратной чешуйчатой ретушью (рис. 5, 4);

- сколы без ретуши: дистальный фрагмент пластины, медиальный фрагмент пластинчатого отщепа, нуклевидный обломок со сколами опробования и три фрагмента сколов;

- мелкие фрагменты лепной керамики (8 экз.) и четыре мелких фрагмента костей, предположительно MPC.

Обсуждение результатов и выводы

Результаты работ показывают очень слабую концентрацию археологического материала в шурфах и рекогносцировочном раскопе Толеубулак 3. Перспективными для исследования являются окрестности родников Андакулбулак и Толеубулак, где имеются погребенные отложения. Заложенный возле родника Толеубулак шурф № 2 показывает: погребенные отложения, мощностью около $50 \mathrm{~cm}$, представляют собой делювиальный шлейф из гипсометрически выше расположенных террас, что не позволяет интерпретировать его как инситные отложения. Обнаруженный в шурфе материал является однородным с подъемными сборами на дневной поверхности.

Шурф № 10, расположенный на площадке террасы, в 130 м северовосточнее родника, представляет собой памятник смешанного типа, где встречаются как материалы позднего палеолита, так и неолита. На дневной поверхности недалеко от шурфа был обнаружен одноплощадочный нуклеус для пластин призматической формы из кремнистого аргиллита размерами $63 \times 30 \times 25$ мм. Ударная площадка прямая, образована одним снятием. Фронт скалывания занимает $3 / 4$ периметра, содержит негативы снятия пластин шириной от 3,5 до 9 мм. Контрфронт покрыт коркой белесого оттенка (рис. 2, 8).

Шурфы № 7 и 8, заложенные возле родника Андакулбулак, с относительно мощными погребенными отложениями с каменными артефактами, фрагментами керамики и костей, также свидетельствуют о перспективности открытия как стратифицированных неолитических-энеолитических объектов, так и поселений эпохи бронзы. Из-за близкого расположения к строениям этнографического периода рыхлые отложения были подвергнуты антропогенному воздействию и являются в верхней части переотложенными.

Анализ раскопа Толеубулак 3 показывает более высокую концентрацию артефактов в центральной и южной части, находящихся гипсометрически ниже северной, что связано с делювиальными процессами на- 
копления отложений в более низких частях. Материал разновременный, представлены и фрагменты керамики эпохи бронзы. Собранные каменные артефакты изготовлены преимущественно из кварцитовидного песчаника светло-серых, темно-серых и красноватых оттенков. Реже на памятнике встречаются изделия из кремня и других пород. Такая дифференциация в сырьевом отношении обусловлена отсутствием в округе выходов кремнистых пород камня. В 2020 г. здесь же был обнаружен технический скол с площадки нуклеуса для снятия пластин из кремня черного цвета, призматической формы, что свидетельствует о том, что сырье приносилось на памятник в виде заготовок, из которых впоследствии получали сколы для изготовления орудий. В первичном расщеплении характерно изготовление отщепов средних размеров, на это указывают нуклеусы и нуклевидные обломки, содержащие негативы снятий отщепов шириной от 30 до 80 мм, a также отходы производства. Орудийный набор в коллекции составляет $32 \%$ от общего числа находок, представлен сколами со вторичной обработкой (ретушью) - режущие и рубящие орудия, реже скребки.

Единичный памятник с погребенным слоем предположительно неолит-энеолитического времени на территории Актюбинской области известен на берегу р. Сарымурза, левого притока второго порядка р. Орь (Op)? [Сегедин, 1974]. Однако материал, собранный Р.А. Сегединым с дневной поверхности и из шурфа, представлен грубыми сколами из брекчиевидной кремнистой породы серых оттенков, не похож на материалы, обнаруженные в окрестности Толеубулака. Ближайшие аналогии в типах сырья, а также в технологии расщепления (призматический нуклеус) и типах орудий имеются среди подъемных комплексов стоянки Каинды 2, обнаруженных в Южных Мугоджарах (Мугалжарах)? на берегу одноименной реки [Сегедин, 1976].

Сделать более детальный вывод в отношении каменной индустрии стоянки невозможно по причине малочисленности коллекции.

На сравнительно небольшой площади возле и в окрестностях грота Толеубулак были собраны разновременные каменные артефакты от палеолита до эпохи бронзы, что свидетельствует о постоянном функционировании археологического комплекса и перспективах обнаружения стратифицированных стоянок и поселений в окрестностях.

\section{ЛИТЕРАТУРА}

1. Деревянко А.П., Петрин В.Т., Таймагамбетов Ж.К., Зенин А.Н., Гладышев С.А. Палеолитические комплексы поверхностного залегания Мугоджарских гор // Проблемы археологии, этнографии, антропологии Сибири и сопредельных территорий. Новосибирск: Изд-во ИАЭт СО РАН, 1999. С. 50-55.

2. Деревянко А.П., Петрин В.Т., Гладышев С.А., Зенин А.Н., Таймагамбетов Ж.К. Ашельские комплексы Мугоджарских гор (Северо-Западная Азия). Новосибирск: ИАЭт СО РАН, 2001а. 136 с.

3. Деревянко А.П., Петрин В.Т., Гладышев С.А., Таймагамбетов Ж.К., Ламин В.В., Искаков Г., Абсадык Ж. Открытие петроглифов в верховьях р. Эмба в Мугоджарских 
горах // Проблемы археологии, этнографии и антропологии Сибири и сопредельных территорий. Новосибирск: Изд-во ИАЭт СО РАН, 2001б. Т. VII. С. 100-103.

4. Деревянко А.П., Петрин В.Г., Зенин А.Н., Таймагамбетов Ж.К., Гладышев С.А., Цыбанков А.А., Славинский В.С. Каменный век Казахстана: Исследования Российскоказахстанской археологической экспедиции в Казахстане (1998-2001). Новосибирск: Изд-во ИАЭт СО РАН, 2003. 184 с.

5. Мамиров Т.Б., Таймагамбетов Ж.К., Байтлеу Д.А., Мамиров К.Б. Памятники эпохи неолита у родника Толеубулак и в верховьях р. Эмба // «Кадырбаевские чтения2020»: м-лы VI Междунар. науч. конф. (г. Актобе, 27-28 ноября 2020 г.) / Отв. ред. А.Б. Уразова. Актобе: Актюбинский областной историко-краеведческий музей, 2020. C. 67-74.

6. Онгар А., Нурпеисов М., Киясбек Г., Логвин А., Жетписбай Н. Археологические памятники микрорайона Толеубулак-Егиндибудак (предварительные итоги работ) // Вопросы истории и археологии Западного Казахстана. 2009. № 1. С. 197-213.

7. Самашев 3. Петроглифы Казахстана. Алматы: Өнер, 2006200 с.

8. Сегедин Р.А. Археологические находки в Актюбинской области. Актюбинск, 1974 // Архив ИА КН МОН РК, д. 1306.

9. Сегедин Р.А. Отчет об археологических находках 1974-1975 гг. в Мугоджарах (Актюбинская область). Актюбинск, 1976 // Архив ИА КН МОН РК, д. 1411.

10. Сойкина Н.Ю. Живопись эпохи палеолита в системе культурных ценностей Евразии: автореф. дис. ... канд. ист. наук: 07.00.06. Алматы, 2009. 30 с.

11. Таймагамбетов Ж.К. Еще раз об открытии и исследовании петроглифов голоценового периода грота Эмба (Толеубулак) // Археология Казахстана. 2020. № 3 (9). C. 20-29.

12. Таймагамбетов Ж.К., Мамиров Т.Б. Новые палеолитические памятники в Мугалжарах // «Кадырбаевские чтения - 2010»: м-лы II Междунар. науч.-практ. конф. (г. Актобе). / Науч. ред. А.А. Бисембаев. Актобе: Областной центр истории, этнографии и археологии, 2010. С. 33-37.

13. Таймагамбетов Ж.К., Сойкина Н.Ю. Искусство палеолита Евразии. Алматы: Хантәңірі, 2016. $231 \mathrm{c.}$

\section{REFERENCES}

1. Derevyanko, A. P., Petrin, V. T., Gladyshev, S. A., Zenin, A. N., Taimagambetov, Zh. K., Iskakov, G. T. 1999. In: Problemy arheologii, etnografii, antropologii Sibiri $i$ sopredelnyh territoriy (Problems of archeology, ethnography, anthropology of Siberia and adjacent territories). Novosibirsk: Siberian branch Institute of archaeology and ethnography of the Russian academy of sciences, 50-55 (in Russian).

2. Derevyanko, A. P., Petrin, V. T., Gladyshev, S. A., Zenin, A. N., Taimagambetov, Zh. K. 2001. Ashelskie kompleksy Mugodzharskih gor (Severo-Zapadnaya Aziya) (Asheulian complexes of the Mugodzhar mountains (North-West Asia)). Novosibirsk: Siberian branch Institute of archaeology and ethnography of the Russian academy of sciences (in Russian).

3. Derevyanko, A. P., Petrin, V. T., Gladyshev, S. A., Taimagambetov, Zh. K., Lamin, V. V., Iskakov, G. T., Absadyk, Zh. 2001. In: Problemy arheologii, etnografii, antropologii Sibiri i sopredelnyh territorij (Problems of archeology, ethnography, anthropology of Siberia and adjacent territories), VII. Novosibirsk: Siberian branch Institute of archaeology and ethnography of the Russian academy of sciences, 100-103 (in Russian).

4. Derevyanko, A. P., Petrin, V. T., Zenin, A. N., Taimagambetov, Zh. K., Gladyshev, S. A., Tsybankov, A. A., Slavinskiy, V. S. 2003. Issledovaniya Rossiysko-Kazahstanskoy ekspeditsii $v$ Kazahstane (1998-2001 gg.) (Research of the Russian-Kazakh expedition in Kazakhstan 
(1998-2001)). Novosibirsk: Siberian branch Institute of archaeology and ethnography of the Russian academy of sciences (in Russian).

5. Mamirov, T. B., Taimagambetov, Zh. K., Baitileu, D. A., Mamirov, K. B. In: Urazova, A. B. (ed.). Kadyrbaevskie chteniya-2020 (Kadyrbayev readings-2020). Aktobe: Aktyubinskiy oblastnoy istoriko-kraevedcheskiy muzey, 67-74 (in Russian).

6. Onggar, A., Nurpeisov, M., Kiyasbek, G., Logvin, A., Jetpisbay, N. 2009. In: Voprosy istorii i arheologii Zapadnogo Kazahstana (Questions of history and archeology of Western Kazakhstan), 1, 197-213 (in Russian).

7. Samashev, Z. 2006. Petroglify Kazahstana (Petroglyphs of Kazakhstan). Almaty: “Oner” Publ. (in Russian).

8. Segedin, R. A. 1974. In: Archive of A.Kh. Margulan Archaeology Institute, d. 1306.

9. Segedin, R. A. 1976. In: Archive of A.Kh. Margulan Archaeology Institute, d. 1411.

10. Soykina, N. Yu. 2009. Zhivopis epohi paleolita v sisteme kulturnyh tsennostey Evrazii (Paleolithic painting in the system of cultural values of Eurasia): thesis of the Cand. Hist. sciences. Almaty (in Russian).

11. Taimagambetov, Zh. K. 2020. In: Kazakhstan Archeology, 3 (9), 20-29 (in Russian).

12. Taimagambetov, Zh. K., Mamirov, T. B. 2010. In: Bisembaev, A. A. (ed.). Kadyrbaevskie chteniya-2010 (Kadyrbayev readings-2010). Aktobe: Aktyubinskiy oblastnoy tsentr istorii, etnografii i arheologii, 33-37 (in Russian).

13. Taimagambetov, Zh. K., Soykina, N. Yu. 2016. Iskusstvo paleolita Evrazii (Paleolithic art of Eurasia). Almaty: "Hantaniri”" Publ. (in Russian).

Мүдделер қақтығысы туралы ақпаратты ашу. Автор мүдделер қақтығысының жоқтығын мәлімдейді.

/ Раскрытие информации о конфликте интересов. Автор заявляет об отсутствии конфликта интересов.

/ Disclosure of conflict of interest information. The author claims no conflict of interest.

Мақала туралы ақпарат / Информация о статье / Information about the article.

Редакцияға түсті / Поступила в редакцию / Entered the editorial office: 21.10.2021.

Рецензенттер мақұлдаған / Одобрено рецензентами / Approved by reviewers: 30.10.2021.

Жариялауға қабылданды / Принята к публикации / Accepted for publication: 30.10.2021. 